Original Article

\title{
Filtrates from cultures of endophytic fungi isolated from leaves of Copaifera oblongifolia (Fabaceae) affect germination and seedling development differently
}

\author{
Fungos endofíticos isolados de folhas de Copaifera oblongifolia (Fabaceae) afetam \\ diferentemente a germinação e o desenvolvimento das plântulas
}

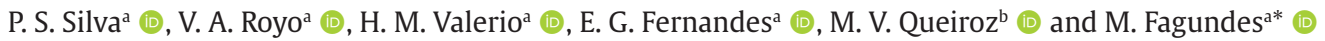 \\ aUniversidade Estadual de Montes Claros - Unimontes, Departamento de Biologia Geral, Programa de Pós-graduação em Biodiversidade \\ e Uso dos Recursos Naturais, Montes Claros, MG, Brasil \\ bUniversidade Federal de Viçosa - UFV, Instituto de Biotecnologia Aplicada à Agropecuária - BIOAGRO, Departamento de Microbiologia, \\ Laboratório de Genética Molecular de Fungos, Viçosa, MG, Brasil
}

\begin{abstract}
Interactions between endophytic fungi (EFs) and their host plants range from positive to neutral to negative. The results of such interactions can vary depending on the organ of the infected host plant. EFs isolated from the leaves of some species of plants have potential for use as agents to inhibit seed germination and control invasive plants. The objectives of this study were to identify EFs present in the leaves of Copaifera oblongifolia and to evaluate the role of these fungi in seed germination and seedling development. A total of 11 species of EFs were isolated, which were identified using the internal transcribed spacers (ITS) sequence of the nuclear ribosomal DNA. The isolated species of EFs are generalists and probably are transmitted horizontally. Laboratory tests revealed that filtrates of these fungal isolates differently affect seed germination and seedling development of $C$. oblongifolia. The species Curvularia intermedia, Neofusicoccum parvum, Pseudofusicoccum stromaticum and Phomopsis sp. negatively affected seed germination, with N. parvum standing out for its negative effects, inhibiting seedling germination and survival in 89 and $222 \%$, respectively. In addition, Cochliobolus intermedius negatively affected seedling development. Thus, the combined use of $N$. parvum and C. intermedius, or products from the metabolism of these microorganisms, in the control of invasive plants deserves attention from future studies.
\end{abstract}

Keywords: Brazilian Cerrado, diversity of endophytic fungi, germination inhibition, plant-fungi interactions, species management.

\begin{abstract}
Resumo
As interações entre fungos endofíticos (FEs) e suas plantas hospedeiras variam de positivas, neutras a negativas. Os resultados destas interações podem variar dependendo do órgão da planta hospedeira infectada. FEs isolados de folhas de algumas espécies de plantas têm potencial para serem usados como agentes inibidores da germinação de sementes e no controle de plantas invasoras. Os objetivos deste estudo foram identificar os FEs presentes nas folhas de Copaifera oblongifolia e avaliar o papel destes fungos na germinação das sementes e no desenvolvimento das plântulas. Um total de 11 espécies de FEs foi isolado das folhas de C. oblongifolia e identificado através da sequência dos espaçadores internos transcritos do DNA ribossomal nuclear. As espécies de FEs isoladas são generalistas e provavelmente devem ser transmitidas horizontalmente. Os resultados dos testes de germinação mostraram que filtrados destes isolados fúngicos podem afetar diferentemente a germinação das sementes e o desenvolvimento das plântulas de C. oblongifolia. As espécies Curvularia intermedia, Neofusicoccum parvum, Pseudofusicoccum stromaticum e Phomopsis sp. afetaram negativamente a germinação das sementes de C. oblongifolia. Dentre estas espécies devemos destacar que N. parvum reduziu a germinação e a sobrevivência das plântulas em 89 e $222 \%$, respectivamente. Além disso, Cochiliobolus intermedius afetou negativamente o desenvolvimento das plântulas. Assim, o uso combinado de N. parvum e C. intermedius, ou de produtos do metabolismo destas espécies de fungos, têm potencial para serem usados no manejo de plantas invasoras.
\end{abstract}

Palavras-chave: Cerrado, diversidade de fungos endofíticos, inibição da germinação, interações fungo-planta, manejo de espécies invasoras.

*e-mail: marcilio.fagundes@gmail.com

Received: August 10, 2020 - Accepted: January 28, 2021

This is an Open Access article distributed under the terms of the Creative Commons Attribution License, which permits unrestricted use, distribution, and reproduction in any medium, provided the original work is properly cited. 


\section{Introduction}

Plants interact with a great diversity of microorganisms that can colonize the external surface or internal tissues of different organs (Porras-Alfaro and Bayman, 2011; Hardoim et al., 2015). Endophytic fungi (EFs) normally develop inside plant tissues (Rodriguez et al., 2009; Hardoim et al., 2015; Ripa et al., 2019) and their relationship with the host can vary from positive to neutral to negative (Porras-Alfaro and Bayman, 2011; Lata et al., 2018). Some species of EFs can increase plant tolerance to drought (Redman et al., 2011; Ali et al., 2018; Fa, 2019), inhibit herbivory (Wagner and Lewis, 2000; Lugtenberg et al., 2016), increase seedling vigor (Rai et al., 2014; Lugtenberg et al., 2016) and promote seed germination (Delgado-Sánchez et al., 2011, 2013). Besides, at certain life-cycle stages, some EFs can be harmful to plant development by inhibiting germination (Jiang et al., 2008; Khiralla et al., 2018), reducing seedling biomass (Tilley and Walker, 2002) and causing disease or death of the host (Lombard et al., 2014; Silveira et al., 2018). Therefore, some species of EFs are considered promising agents for the biological control of invasive plants (Jiang et al., 2008; Meepagala et al., 2016).

The transmission of EFs among plants can occur vertically or horizontally. Vertical transmission occurs when parental plants transfer EFs to their offspring through seeds (Lugtenberg et al., 2016; Lata et al., 2018). Horizontal transmission is characterized by the spread of propagules of fungi among hosts through wind, rain or biotic agents such as pollinators and seed dispersers and predators (Lugtenberg et al., 2016). Horizontal transmission is more common (Saikkonen et al., 2004) and occurs mainly among above-ground tissues and organs of plants (Rodriguez et al., 2009; Lugtenberg et al., 2016). Fungi that have horizontal transmission have less host plant specificity (Murali et al., 2006) and represent an important component of the diversity of microorganisms associated with tropical angiosperms (Arnold et al., 2001; Hawksworth, 2004; Arnold, 2007). Despite this wide diversity, the role of these microorganisms in plant development is still poorly understood (Murali et al., 2006; U'ren et al., 2009; Arora et al., 2019).

Seeds are structures that are rich in carbohydrates, proteins and minerals (Nelson, 2004; Fenner and Thompson, 2005; Bewley et al., 2013), and can be colonized by a diverse array of microorganisms, including EFs, that can be pathogenic or beneficial for seeds (Nelson, 2004; Fernandes et al., 2019). Some EFs are also capable of producing cellulase that degrades the husks of seeds, thereby accelerating seed inhibition and embryo development (Delgado-Sánchez et al., 2011, 2013). Some species of fungi can inhibit germination by producing phytotoxins that affect the triggering metabolic processes (Halloin, 1986; Khiralla et al., 2018), or simply degrade the seeds causing the embryo to die (Fagundes et al., 2011). However, seed-EFs relationships are still poorly understood and may be species-dependent (Qin et al., 2016; Geisen et al., 2017; Fernandes et al., 2019). In addition, EFs found in the leaves of some plant species can inhibit germination and, thus, serve as biological control agents for invasive species (Kluger et al., 2008).

Seed germination can also be affected by intrinsic attributes of the seed itself, such as mass and age. Seed mass is considered a key factor for germination and successful seedling recruitment (Fenner and Thompson, 2005; Fagundes et al., 2020). Larger seeds have a greater amount of nutritional reserves, exhibit higher germination percentages and produce more vigorous seedlings (Cordazzo, 2002; He et al., 2007). In contrast, smaller seeds germinate more quickly and invest proportionately more resources in root development, and thus are favored in transient habitats. Therefore, seed germination is a critical stage in the life cycle of plants, being influenced by several abiotic factors such as light, temperature and humidity (Veloso et al., 2017; Fagundes et al., 2020) and biotic factors such as predators and parasitic or mutualistic microorganisms (Moles and Westoby, 2006; Farias et al., 2015; Fernandes et al., 2019).

Studies related to the regulatory mechanisms of germination are a priority of programs for the management of invasive species that reproduce through seeds (Ozaslan et al., 2017; Oliveira et al., 2021). Copaifera oblongifolia Mart. (Fabaceae) is a tropical shrub that occurs in anthropized areas of the Brazilian Cerrado (Veloso et al., 2017). This plant species often invades cultivated agricultural areas and pastures, causing economic losses for rural producers (Fagundes et al., 2020). The aims of this study were (i) identify EFs associated with the leaves of $C$. oblongifolia and (ii) evaluate the effects of culture filtrates of these EFs on seed germination and seedling development of $C$. oblongifolia.

\section{Materials and Methods}

\subsection{Obtaining leaves and seeds}

The leaves and seeds were collected from adult individuals of $C$. oblongifolia located in a Cerrado area (-17.240, -44.451 UTM), municipality of Jequitaí, northern Minas Gerais state, Brazil. The soil in the study area is dystrophic (Dystrophic Red-yellow Latosol), with low levels or organic matter and poor in nutrients (Coutinho et al., 2019). Geographically, the area is inserted in the region of transition between the Cerrado and Caatinga domains. The climate is classified as Tropical Savanna Climate (Aw), with dry winters and wet summers (Fagundes et al., 2019). The mean annual temperature is $23^{\circ} \mathrm{C}$, with approximately $1000 \mathrm{~mm}$ of rainfall per year that is concentrated between November and February (Alvares et al., 2014; Kuchenbecker and Fagundes, 2018).

\subsection{Isolation of endophytic fungi}

The leaves used to isolate EFs were collected from five adult plant of $C$. oblongifolia. Thus, a branch approximately $30 \mathrm{~cm}$ long was collected from each plant, stored in sterile paper envelopes and transported in a Styrofoam box to Laboratório de Ecologia de Microrganismos e Microbiologia Ambiental da Unimontes. In the Laboratory conditions, 
three mature leaves were removed from each branch and washed thoroughly under running water to remove dust particles from the surface. The leaves were then immersed in $70 \%(\mathrm{v} / \mathrm{v})$ ethanol for 1 minute, followed $3 \%(\mathrm{v} / \mathrm{v})$ sodium hypochlorite for 2 minutes for elimination/disinfection of fast-growing epiphytic fungi. Finally, the leaves were rinsed in distilled water and dried with sterile absorbent paper. After sterilizing leaf surface, a $100 \mathrm{~mm}^{2}$ fragment was removed from each leaf and inoculated into Petri dishes containing a medium of potato dextrose agar (PDA) supplemented with ampicillin $(50 \mu \mathrm{g} / \mathrm{mL})$ to suppress bacterial growth. The Petri dishes were sealed with PVC film and incubated at $25^{\circ} \mathrm{C}$ for one week. After this period, the endophytes present in the plates were transferred to new PDA medium to purify the colonies. After isolation, the fungi were preserved on silica-gel and stored at $4{ }^{\circ} \mathrm{C}$ for later identification through the internal transcribed spacers (ITS) sequence of the nuclear ribosomal DNA.

\subsection{DNA extraction and molecular identification of endophytic fungi}

For DNA extraction, lyophilized fungi were grown in duplicate in Erlenmeyer flasks containing $100 \mathrm{~mL}$ of medium liquid Sabouraud (20 g glucose, $10 \mathrm{~g}$ peptone $\mathrm{G}, 5 \mathrm{~g}$ yeast extract, $1 \mathrm{~L}$ distilled water) and incubated at $25{ }^{\circ} \mathrm{C}$ under orbital shaking at $150 \mathrm{rpm}$ for 7 days. After growth, the fungi were vacuum filtered, stored in aluminum foil and kept in an ultrafreezer at $-76{ }^{\circ} \mathrm{C}$ until DNA extraction. DNA of the isolated fungi was extracted using the Wizard ${ }^{\circledR} G e n o m i c ~ D N A$ Purification Kit (Promega ${ }^{\circledR}$ ), according to the manufacturer's instructions. Finally, the extracted DNA was submitted to quantification and determination of purity using a NanoDrop 2000c spectrophotometer (Thermo Scientific), according to the instructions of the user manual.

The extracted fungal DNA was amplified using the universal primers ITS1 (5'-TCCGTAGGTGAACCTGCGG-3') and ITS4 (5'-TCCTCCGCTTATTGATATGC-3'), according to White et al. (1990), as modified by Gonzaga et al. (2015). The reaction of amplification was carried out in a final volume of $25 \mu \mathrm{L}$ containing $9.25 \mu \mathrm{L}$ of sterile ultrapure water, $5 \mu \mathrm{L}$ Flex Buffer $5 \mathrm{X}$ (Promega ${ }^{\circledR}$ ), $2.5 \mu \mathrm{L}$ of $\mathrm{MgCl}_{2}$ at $25 \mathrm{mM}$ (Promega $\left.{ }^{\circledR}\right), 1 \mu \mathrm{L}$ of $10 \mathrm{mM}$ dNTPs, $1 \mu \mathrm{L}$ of each primer at $5 \mu \mathrm{M}, 0.25 \mu \mathrm{L}$ of GoTaq $5 \mathrm{U} / \mu \mathrm{L}$ DNA polymerase (Promega ${ }^{\circledR}$ ) and $5 \mu \mathrm{L}$ of DNA. The amplification was conducted in a thermocycler (Bio-Rad: $\mathrm{C} 1000^{\mathrm{TM}}$ ), with the following programming: an initial denaturation stage at $95^{\circ} \mathrm{C} / 3$ minutes, followed by 36 cycles of denaturation at $95{ }^{\circ} \mathrm{C} / 1$ minute, annealing at $51{ }^{\circ} \mathrm{C} / 1$ minutes, extension at $72{ }^{\circ} \mathrm{C} / 1$ minute, and a final extension step of $72{ }^{\circ} \mathrm{C} / 10$ minutes.

The amplified ITS fragments were submitted to $1.2 \%$, agarose gel electrophoresis, stained with ethidium bromide and visualized under UV light with a photographic documentation system and L-Pix Chemi Molecular Imaging software (Loccus Biotecnologia). The PCR products were subsequently dried at $60^{\circ} \mathrm{C}$ in an oven and sent to ACTGene Análises Moleculares Ltda. (Centro de Biotecnologia, UFRGS, Porto Alegre, RS, Brazil) for purification and sequencing using the same primers used for DNA amplification.
Sequencing was performed with an AB3500 Genetic Analyzer automatic sequencer equipped with $50 \mathrm{~cm}$ capillaries and POP7 polymer (Applied Biosystems). After sequencing, the sequences of the two DNA strands were grouped into contigs and manually corrected with Sequencher ${ }^{\mathrm{TM}} 4.1 .4$ software (Gene Codes Corporation, Ann Arbor, Michigan, USA). All nucleotide sequences were then compared to sequences deposited in GenBank using NCBI BLAST databases (http://blast.ncbi.nlm.nih.gov/blast/ Blast.cgi). Species identification was based on similarity. The sequences were deposited in GenBank and assigned with the accession numbers MT605128.1 to MT605138.1.

\subsection{Seed collection and germination experiment}

To evaluate the effects of EFs isolated from the leaves of C. oblongifolia on the germination seeds and the development of its seedlings, a total of 2000 seeds, in a visible state of maturity, were collected from 30 individuals in study area. The 30 plants selected for fruit collection were about $1.5 \mathrm{~m}$ tall and spaced at least $15 \mathrm{~m}$ apart. The seeds underwent a phytosanitary status assessment in the laboratory, when malformed seeds or seeds with signs of attacks by predators or pathogens were discarded. Thus, 1800 healthy seeds were selected, which were individually weighed using a precision digital analytical balance (Shimadzu, Model: Ay220) and stored individually in plastic bags.

The 1800 seeds were equally divided among 12 groups of 150 seeds each. Each group was infected with filtrates of one of the fungal isolates (Cochliobolus intermedius, Curvularia intermedia, Diaporthe columnaris, Diaporthe helianthi, Diaporthe heveae, Mycosphaerella nawae, Neofusicoccum parvum, Peyronellaea prosopidis, Phomopsis sp., Pseudofusicoccum stromaticum and Fungi sp.) found in the leaves of $C$. oblongifolia or with sterile distilled water (control), and thus represented the 12 treatments of the germination experiment. The filtrate of each EF species was obtained by culture rotation in solid and liquid medium to keep the cultures renewed every 10 days. First, silica fungi were grown in Petri dishes containing solid PDA medium and incubated at temperature of $25^{\circ} \mathrm{C}$ in an oven for five days. Next, 10 x $10 \mathrm{~mm}$ fragments of mycelium of each fungus were transferred to $250 \mathrm{~mL}$ Erlenmeyer flasks containing $200 \mathrm{~mL}$ liquid potato dextrose medium (200 g potato, 15 g glucose and $1 \mathrm{~L}$ distilled water) and incubated at $25^{\circ} \mathrm{C}$ under orbital shaking at $150 \mathrm{rpm}$ for 10 days in the dark. Finally, the solution of each EFs were filtered through four layers of gauze (100 - micron mesh), and the filtered fungal cultures kept in a refrigerator at $4{ }^{\circ} \mathrm{C}$ for 10 days. Every 10 days the filtered fungi cultures were renewed. Each culture was grown in duplicate.

All 150 seeds of each treatment were then incubated in sterile glass Petri dishes (90 $\mathrm{mm}$ in diameter) for germination. Ten seeds were incubated in each Petri dish in a specific position so that the germination of each could be monitored individually allowing access to possible effects of seed mass on germination. Before incubation in Petri dishes, all seeds were disinfected by immersion in ethanol $70 \%(\mathrm{v} / \mathrm{v})$ for 1 minute, followed by 2 minutes in $3 \%(\mathrm{v} / \mathrm{v})$ sodium hypochlorite $(\mathrm{NaOCl})$, followed by washes 
in sterile distilled water before sowing in the Petri dishes (Fernandes et al., 2015). Sterile vermiculite (2 g per Petri dish) was used as a substrate for germination.

All Petri dishes with 10 seeds each were incubated in a germination chamber (B.O.D.) with a $12 \mathrm{hr}$ photoperiod, constant temperature of $25^{\circ} \mathrm{C}$ and luminosity equivalent of $47.5 \mu \mathrm{mol} \mathrm{m-2} \mathrm{s}^{-1}$ of irradiation. The seeds belonging to the control treatment were irrigated with $1 \mathrm{~mL}$ of sterile distilled water every two days (dosage and number of days established according to field capacity testing), while the seeds of the other treatments were irrigated every two days with $1 \mathrm{~mL}$ of culture filtrate of the corresponding EF species isolated form $C$. oblongifolia leaves. The seeds were monitored daily to determine the germination percentage and the time required for germination. The seeds were considered germinated when they had primary radicle emission.

\subsection{Seedling establishment experiment}

A total of 30 seedlings from each of the germination bioassay treatments were transferred to 12 different germination trays. Each tray consisted of 30 individual cells ( $2 \mathrm{~cm}$ long, $2 \mathrm{~cm}$ wide and $3 \mathrm{~cm}$ high). The cells in each tray were properly identified and filled with $3.5 \mathrm{~g}$ of sterile vermiculite. After transplanting the germinated seeds, the trays were incubated in B.O.D. with a constant temperature of $25^{\circ} \mathrm{C}$, a photoperiod of 12 hours and $47.5 \mu \mathrm{mol} \mathrm{m}-{ }^{2} \mathrm{~s}-{ }^{1}$ of irradiation. Each seedling was irrigated daily with $2.5 \mathrm{~mL}$ of sterile water. Seedling development was monitored until cotyledons fell. Thus, the time between seed germination and the fall of cotyledons was defined as the development time. After the cotyledons fell, the seedlings were removed from the substrate to determine their biomass. Thus, the root system and the aerial part of each seedling were separated and weighed individually with a precision digital analytical balance (Shimadzu, Model: Ay220).

\subsection{Statistical analysis}

Two generalized linear models (GLMs) were constructed to evaluate the effect of treatments and seed biomass on germination percentage and the time required for germination. In these models, germination percentage or time required to seed germination were the response variable, and treatments, seed biomass and the interactions between these variables were explanatory variables. The Binomial (corrected for Quasibinomial) or Gaussian error distributions were used, respectively, when germination percentage and time for germination were used as responses variables. The both models were tested by analysis of variance (ANOVA).

To test the effects of treatments and seed biomass on seedling vigor, four GLMs were built and tested by analysis of variance (ANOVA). In these models, seedling survival, aerial biomass, root biomass or seedling biomass were used as the response variable, and treatments, seed biomass and the interaction between these variables as the explanatory variables. The Binomial distribution (corrected for Quasibinomial) was used in the construction of the model with seedling survival as the response variable, while the Gaussian distribution was most adequate for the other models. All of the models were submitted to Residual Analysis to adjust the model to error distribution for each response variable (Crawley, 2013). All significant models with more than two levels were subjected to contrast analysis to group statistically equal levels and to separate statistically different levels. All statistical analyses were performed using R software version 3.6.3 (R Core Team, 2020).

\section{Results}

A total of 11 species of EFs were isolated from the leaves of Copaifera oblongifolia (Table 1), only one of which was not identified. All the identified species belong to the phylum

Table 1. Endophytic fungi isolated from leaves of the Copaifera oblongifolia (Fabaceae). The fungi were identified using the internal transcribed spacers (ITS) sequence of the nuclear ribosomal DNA.

\begin{tabular}{|c|c|c|c|c|c|c|}
\hline Code & Closest match in NCBI & $\begin{array}{c}\text { Number } \\
\text { accession }\end{array}$ & $\begin{array}{c}\text { Number } \\
\text { accession } \\
\text { deposited }\end{array}$ & $\begin{array}{c}\text { Similarity } \\
(\%)\end{array}$ & Order & Class \\
\hline PRJ1 & Cochliobolus intermedius & HE861854.1 & MT605137.1 & $99 \%$ & Pleosporales & Dothideomycetes \\
\hline PRJ2 & Curvularia intermedia & KU856622.1 & MT605134.1 & $100 \%$ & Pleosporales & Dothideomycetes \\
\hline PRJ3 & Diaporthe columnaris & MN058043.1 & MT605128.1 & $95 \%$ & Diaporthales & Sordariomycetes \\
\hline PRJ4 & Diaporthe helianthi & KR812218.1 & MT605135.1 & $99 \%$ & Diaporthales & Sordariomycetes \\
\hline PRJ5 & Diaporthe heveae & KR812219.1 & MT605131.1 & $99 \%$ & Diaporthales & Sordariomycetes \\
\hline PRJ6 & Mycosphaerella nawae & KX881942.1 & MT605138.1 & $97 \%$ & Capnodiales & Dothideomycetes \\
\hline PRJ7 & Neofusicoccum parvum & MF449515.1 & MT605130.1 & $99 \%$ & Botryosphaeriales & Dothideomycetes \\
\hline PRJ8 & Peyronellaea prosopidis & MG323882.1 & MT605129.1 & $99 \%$ & Pleosporales & Dothideomycetes \\
\hline PRJ9 & Phomopsis sp. & HE585016.1 & MT605132.1 & $99 \%$ & Diaporthales & Sordariomycetes \\
\hline PRJ10 & Pseudofusicoccum stromaticum & KT728919.1 & MT605133.1 & $100 \%$ & Botryosphaeriales & Dothideomycetes \\
\hline PRJ11 & Fungal sp. & GQ996125.1 & MT605136.1 & $85 \%$ & & \\
\hline
\end{tabular}


Ascomycota and represent the classes Dothideomycetes (6 isolates) and Sordariomycetes (4 isolates). These fungi belong to four orders (Botryosphaeriales, Capnodiales, Diaporthales and Pleosporales) and eight distinct genera (Cochliobolus, Curvularia, Diaporthe, Mycosphaerella, Neofusicoccum, Peyronellaea, Phomopsis and Pseudofusicoccum), with Diaporthe being the most common genus with three species.

The seeds of $C$. oblongifolia started to germinate on the $6^{\text {th }}$ day post-sowing and continued until the $65^{\text {th }}$ day. Germination percentage and average time required for germination were affected by the EF infection treatments (Table 2). In addition, the results of the contrast analyses indicated that the seeds irrigated with filtrate of the fungus $N$. parvum had the lowest germination percentage. The seeds irrigated with filtrates of the fungi $C$. intermedius, C. columnaris, D. helianthi, D. heveae, Fungi sp. (MT605136.1), M. nawae, P. prosopidis and control had high germination percentages, while those of $C$. intermedia, $P$. stromaticum and Phomopsis sp. were intermediate (Figure 1A). The contrast analyses also showed that seeds irrigated with the filtrate of the fungus $D$. columnaris took the most time to germinate, followed by seeds irrigated with the filtrates of the fungi C. intermedia, C. intermedius, M. nawae, N. parvum and $P$. prosopidis. Seeds irrigated with the filtrate of the fungi $D$. helianthi, D. heveae, Fungi sp., P. stromaticum, Phomopsis sp. and the control had the shortest germination time (Figure 1B).

Seedling survival was also affected by treatment (irrigation with filtrates of $\mathrm{EFs}$ ) and the interaction between treatment and seed biomass (Table 3 ). The results of the contrast analyses indicated that seedlings from seeds inoculated with filtrates of $N$. parvum had lower survival than seeds from the other treatments (Figure 2). In addition, the significant interaction between seed mass and treatments indicated that the effects of treatments may vary depending on seed mass. In fact, the survival of seedlings from seeds inoculated with filtrate of $N$. parvum showed a positive correlation with seed mass, while seedlings from seeds of other treatments showed a negative relationship with seed mass (Figure 2B).

Aerial biomass, root biomass and total biomass of seedlings were similarly affected by irrigation with EFs filtrates and seed mass (Table 3). The results of the contrast analyses show that seedlings inoculated with the fungi C. intermedia, D. columnaris, D. helianthi, D. heveae, Fungi sp., M. nawae, N. parvum, P. prosopidis, P. stromaticum and Phomopsis sp. had higher aerial biomass (Figure 3A),

Table 2. Analysis of Deviance showing the effects of explanatory variables (treatment, seed biomass and treatment*seed biomass) on the variables responses (percentage of germination and time of germination) of Copaifera oblongifolia seeds

\begin{tabular}{llccccc}
\hline \multicolumn{1}{c}{$\begin{array}{c}\text { Response } \\
\text { variable }\end{array}$} & \multicolumn{1}{c}{$\begin{array}{c}\text { Explanatory } \\
\text { variable }\end{array}$} & $\begin{array}{c}\text { Error } \\
\text { distribution }\end{array}$ & Deviance & DF Residual & F & $\boldsymbol{P}$ \\
\hline $\begin{array}{l}\text { Germination } \\
(\%)\end{array}$ & Treatment & Quasibinomial & 173.082 & 1,788 & 15.614 & $<0.001$ \\
& Seed mass & & 0.884 & 1,787 & 0.878 & 0.349 \\
& Treatment*seed & & 8.123 & 1,776 & 0.733 & 0.707 \\
& mass & & & & & \\
Time for seed \\
germination & Treatment & Gaussian & $16,583.5$ & 1,544 & 9.174 & $<0.001$ \\
& Seed mass & & 143.1 & 1,543 & 0.871 & 0.351 \\
& Treatment*seed & & $2,711.1$ & 1,532 & 1.499 & 0.125 \\
\hline
\end{tabular}
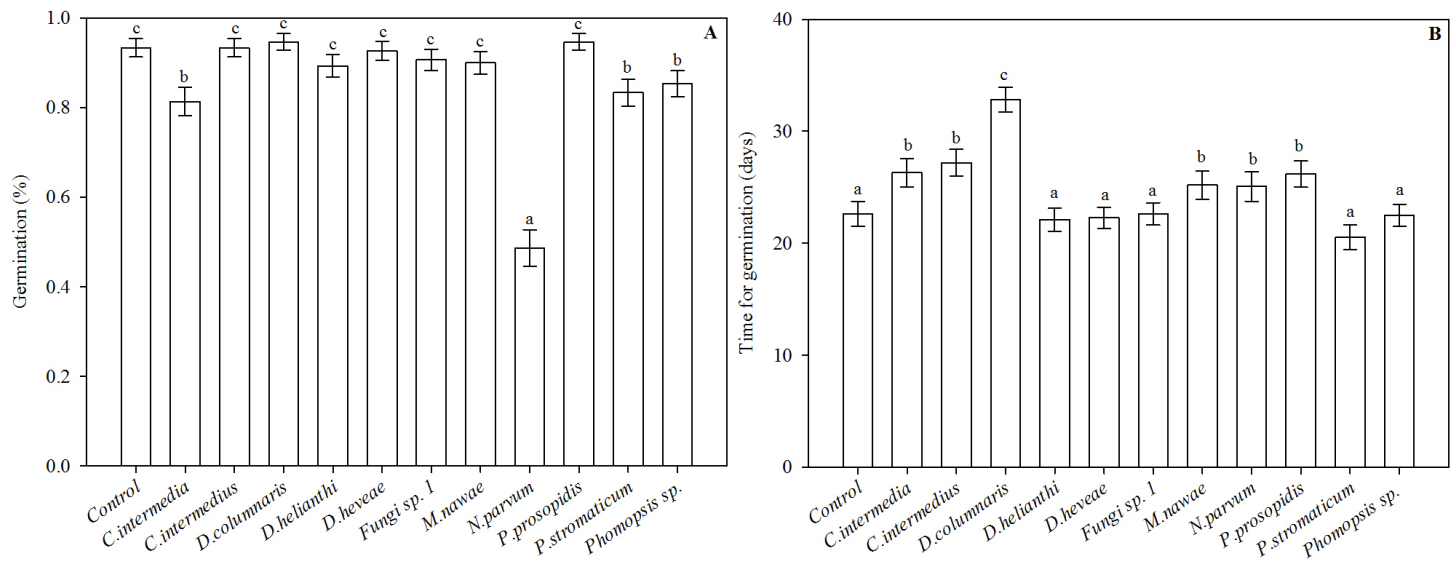

Figure 1. Variations (mean \pm standard error) of the germination percentage (A) and the time required for germination (B) of Copaifera oblongifolia seeds as a function of treatments with inoculation of different species of endophytic fungi. Different letters on the bars indicate statistical variations between treatments $(\mathrm{P}<0.05)$ according contrast analysis. 

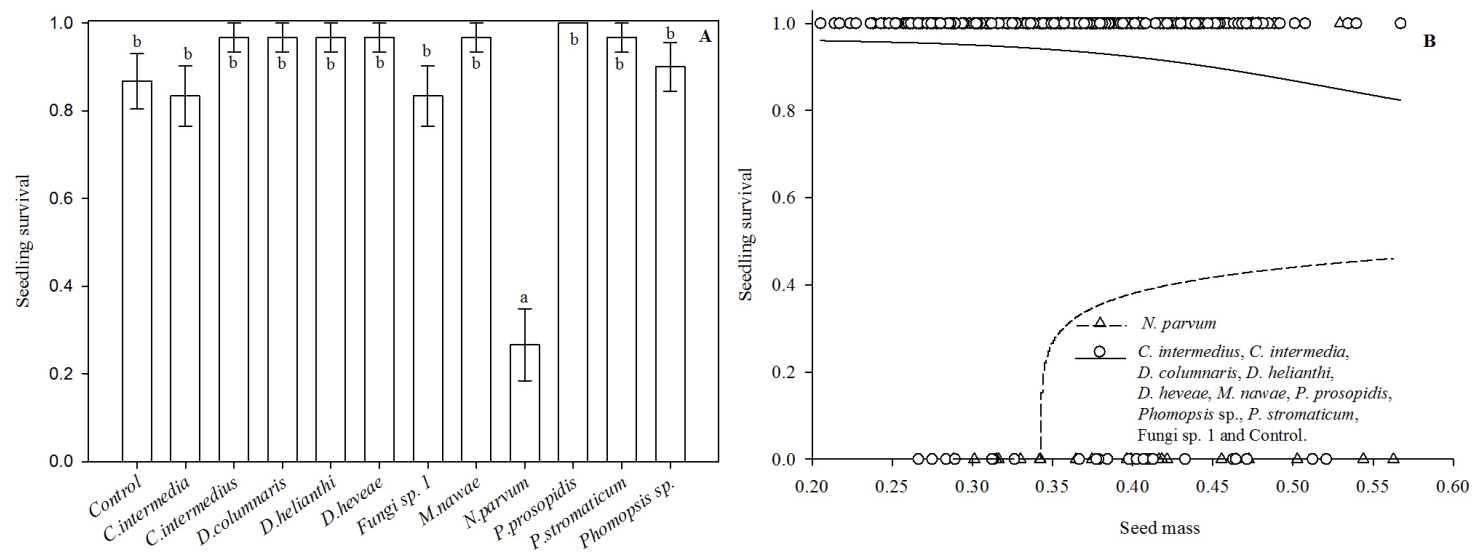

Figure 2. Variations (mean \pm standard error) of seedling survival (A) and its relationship with seed mass (B) of Copaifera oblongifolia as a function of treatments with inoculation of different species of endophytic fungi. Different letters on the bars indicate statistical variations between treatments $(\mathrm{P}<0.05)$ according contrast analysis

Table 3. Analysis of Deviance showing the effects of explanatory variables (treatment, seed mass and treatment*seed biomass) on the variables responses (seedling survival, aerial biomass, root biomass and total seedling biomass) of Copaifera oblongifoliaseedlings.

\begin{tabular}{|c|c|c|c|c|c|c|}
\hline $\begin{array}{l}\text { Response } \\
\text { variable }\end{array}$ & Explanatory variable & $\begin{array}{c}\text { Error } \\
\text { distribution }\end{array}$ & Deviance & DF Residual & $\boldsymbol{F}$ & $\boldsymbol{P}$ \\
\hline \multirow{3}{*}{$\begin{array}{l}\text { Seedling } \\
\text { survival }\end{array}$} & Treatment & Quasibinomial & 86.735 & 348 & 10.838 & $<0.001$ \\
\hline & Seed mass & & 0.597 & 347 & 0.821 & 0.3657 \\
\hline & Treatment*seed mass & & 20.936 & 336 & 2.616 & 0.0033 \\
\hline \multirow[t]{3}{*}{ Aerial mass } & Treatment & Gaussian & 0.3237 & 303 & 3.782 & $<0.001$ \\
\hline & Seed mass & & 0.6678 & 302 & 85.823 & $<0.001$ \\
\hline & Treatment*seed mass & & 0.1215 & 291 & 1.419 & 0.1633 \\
\hline \multirow[t]{3}{*}{ Root mass } & Treatment & Gaussian & 0.0675 & 303 & 3.007 & $<0.001$ \\
\hline & Seed mass & & 0.1056 & 302 & 51.719 & $<0.001$ \\
\hline & Treatment*seed mass & & 0.0237 & 291 & 1.059 & 0.3948 \\
\hline \multirow{3}{*}{$\begin{array}{l}\text { Total } \\
\text { seedling } \\
\text { mass }\end{array}$} & Treatment & Gaussian & 0.5478 & 303 & 3.919 & $<0.001$ \\
\hline & Seed mass & & 13.045 & 302 & 102.681 & $<0.001$ \\
\hline & Treatment*seed mass & & 0.2092 & 291 & 1.497 & 0.1315 \\
\hline
\end{tabular}

root biomass (Figure 3B) and total biomass (Figure 3C), than seedlings inoculated with $D$. intermedius. In addition, the aerial biomass (Figure 4A), root biomass (Figure 4B), and total biomass of seedlings (Figure $4 C$ ) have positive relationship with seed biomass.

\section{Discussion}

A total of 11 EFs were isolated from leaves of Copaifera oblongifolia. EFs found in the leaves of tropical pioneer plants are, in general, generalists and can negatively affect seed germination and seedling development (Kluger et al., 2008). Copaifera oblongifolia is a tropical shrub invader of habitats in the initial stage of succession and does not have EFs associated with its seeds (Fernandes et al., 2019). Therefore, the fungi found in the leaves of $C$. Oblongifolia must have been propagated horizontally. Some of the isolated EF species negatively affected seed germination (e.g. C. intermedia, N. parvum, P. stromaticum and Phomopsis sp.) or seedling development (e.g. N. parvum) of C. oblongifolia. In addition, we observed that none of these EF species have a positive effect on seed germinability or seedling development of $C$. oblongifolia.

All 11 species of EFs isolated from the leaves of C. oblongifolia belong to the phylum Ascomycota. This group of fungi represents a significant portion of the total diversity of fungi (Arnold et al., 2000; Arnold and Lutzoni, 2007) and is dominant in the leaves of plants in tropical environments (Lugtenberg et al., 2016). Endophytic ascomycetes are, in general, generalists (i.e., occur on different plant species) but have specificity with regard to plant organ. The majority EFs isolated from C. oblongifolia have been previously recorded in leaves of other plant species. For 

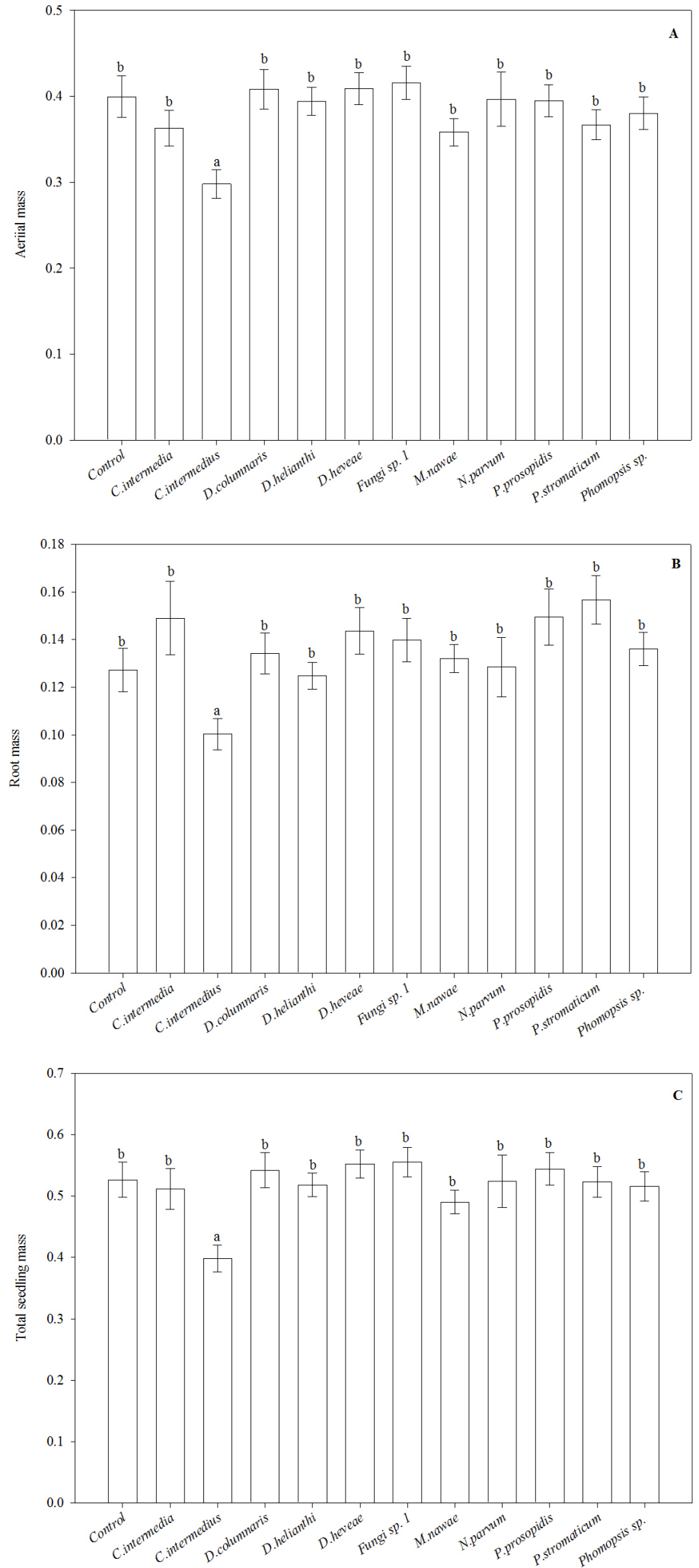

Figure 3. Variations (mean \pm standard error) of aerial mass (A), root mass (B) and total seedling mass (C) of Copaifera oblongifolia as a function of treatments with inoculation of different species of endophytic fungi. Different letters on the bars indicate statistical variations between treatments $(\mathrm{P}<0.05)$ according contrast analysis 

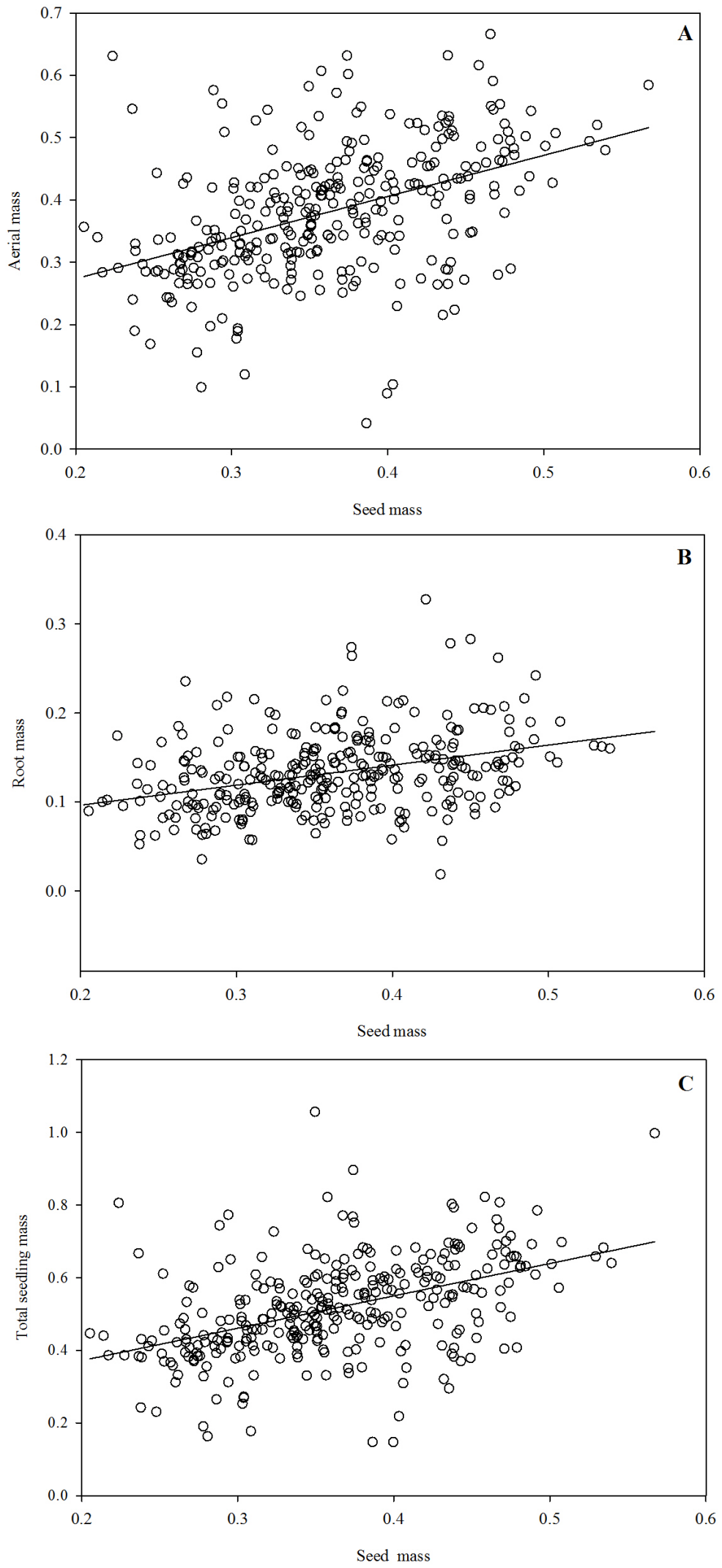

Figure 4. The relationship between aerial mass (A), root mass (B) and total seedling mass (C) with seed mass of Copaifera oblongifolia. 
example, the species $D$. helianthi, $D$. heveae, $N$. parvum, $P$. prosopidis and Phomopsis sp. have been isolated form leaves of Glycine max (Fernandes et al., 2015). Phomopsis sp. was also found in leaves of Quercus ilex (Fisher et al., 1994) and Guarea guidonia (Gamboa and Bayman, 2001). The fungus $C$. intermedia ( $C$. intermedius) was recorded in Digitaria sp. (Tilley and Walker, 2002) and Pandanus amaryllifolius (Meepagala et al., 2016), while C. intermedius was isolated from leaves of Musa sp. (Zakaria and Aziz, 2018), Oryza australiensis (Pak et al., 2017) and Sapindus saponaria (Garcia et al., 2012). In addition, P. prosopidis was found in leaves of Vellozia gigantea (Ferreira et al., 2017); P. columnaris (D. columnaris) in leaves of Olea europaea (Martins et al., 2016); M. nawae in Diospyros kaki (Berbegal et al., 2011; Bassimba et al., 2017) and P. stromaticum in Syzygium malaccense (Silveira et al., 2018).

The germination bioassay showed that the fungus species Phomopsis sp., P. stromaticum, C. intermedia and $N$. parvum negatively affected the germination percentage of $C$. oblongifolia seeds. It should be noted that $N$. parvum reduced seed germination by approximately $89 \%$ relative to the control treatment. In addition, six of the EF species (D. columnaris, C. intermedia, C. intermedius, M. nawae, $N$. parvum and $P$. prosopidis) negatively affected the germination speed of $C$. oblongifolia seeds.

Several studies have shown that EFs can inhibit (Jiang et al., 2008; Meepagala et al., 2016; Mazarotto et al., 2019), stimulate (Tudzynski and Sharon, 2002; Gallery et al., 2007; Khan et al., 2017) or not affect (Fernandes et al., 2019) the seed germination of different plant species. Germination inhibition can occur through the production of phytoinhibitors (Meepagala et al., 2016; Khiralla et al., 2018) or simply through the degradation of seed reserves, causing starvation and death of the embryo (Dhingra et al., 2002; Fagundes et al., 2013). For example, species of Cochliobolus are able to inhibit barley seed germination through the production of the phytotoxin sorokininin (Khiralla et al., 2018). The fungus Curvularia eragrostidis is considered a biological control agent for the weed Digitaria sanguinalis because it inhibits seed germination through the production of $\alpha \beta$-dehydrocurvularin (Jiang et al., 2008; Zhu and Qiang, $2004)$. In addition, the toxin $\alpha \beta$-dehydrocurvularin and curvularin from $C$. intermedia culture broth are also capable of inhibiting the germination of lettuce and grass seeds (Meepagala et al., 2016).

Although fungi of the genera Diaporthe (Phomopsis), Curvularia (Cochliobolus), Mycosphaerella and Neofusicoccum are considered disease-causing pathogens in several host plants (Lombard et al., 2014; Guarnaccia et al., 2016; Netto et al., 2017; Zakaria and Aziz, 2018; Hassan et al., 2020), the results of this study showed that only N. parvum negatively affected the survival of $C$. oblongifolia seedlings. The inoculation of seeds with $N$. parvum reduced seedling survival by $222 \%$ relative to the control treatment. Neofusicoccum parvum is a widely distributed species, occurring in a wide variety of hosts, and has virulent potential for many species of woody plants (Sakalidis et al., 2013). This species causes severe lesions on the stem, branches and shoots, often resulting in the death of the host (Ismail et al., 2013; Guarnaccia et al., 2016). This fungus has been considered the main disease-causing pathogen in orchards of Vitis vinifera (Baskarathevan et al., 2012),
Mangifera indica (Ismail et al., 2013), Persea americana (Guarnaccia et al., 2016) and Malus domestica (Rusin et al., 2019) and Eucalyptus plantations (Pavlic-Zupanc et al., 2017).

The results of this study also showed that $C$. intermedius negatively affected the development of $C$. oblongifolia seedlings. Some studies have demonstrated the ability of species of this genus or its asexual anamorphic C. intermedia, to affect the development of plants (Walker and Tilley, 1997, 1999; Tilley and Walker, 2002). The damage that this microorganism causes to the host can vary from a simple reduction in biomass to the death of the plant. Although we did not observed symptoms of diseases in the seedlings of $C$. oblongifolia, species of the genus of this fungus usually cause necrosis in the cotyledons that later irradiates to the leaves and stems of the plants (Tilley and Walker, 2002). Species of Curvularia belonging to the Cochliobolus lineage isolated from the grass Digitaria sp. are capable of inhibiting the development of some invasive plants of agricultural crops such as Digitaria sp., Setaria sp., Echinochloa sp. and Sorghum sp. (Walker and Tilley, 1997; 1999). In these studies, the authors treated both species of fungi as complementary, with $C$. intermedius being the perfect stage (teleomorph) of $C$. intermedia. In the present study, $C$. intermedia did not affect the performance C. oblongifolia seedlings, but $C$. intermedius negatively affected the initial development of $C$. oblongifolia. The relationship that $C$. intermedius has with dicotyledonous plants is still poorly understood (Tilley and Walker, 2002) and the role of EFs on host plants may vary depending on the nutritional status of the plant (Arnold et al., 2003; Faeth and Fagan, 2002; Eaton et al., 2011) and environmental variation (U'Ren et al., 2012; Higgins et al., 2014; Lau et al., 2013; Martins et al., 2016).

In summary, the results of this study suggest that EFs isolated from the leaves of $C$. oblongifolia are generalists. Among the 11 species isolated from the leaves of C. oblongifolia, $N$. parvum stood out for its negative effects on seed germination and seeding survival, while C. intermedius negatively affected seedling development. Therefore, it would be interesting to consider the possibility of combining these two fungi, or products from the metabolism of these microorganisms, in possible strategies for biological control of invasive plant species.

\section{Acknowledgements}

The authors would like to thank the Graduate Program of Biodiversity (PPG-BURN) of Unimontes and the Projeto Jequitaí CODEVASF/SEAPA-MG for all the logistical support during the fieldwork. The authors also thank gratefully for grants provided by the Fundação de Amparo à Pesquisa de Minas Gerais (FAPEMIG) and Conselho de Aperfeiçoamento de Pessoal de Nível Superior (CAPES).

\section{References}

ALI, A.H., ABDELRAHMAN, M., RADWAN, U., EL-ZAYAT, S. and ELSAYED, M.A., 2018. Effect of Thermomyces fungal endophyte isolated from extreme hot desert-adapted plant on heat stress 
tolerance of cucumber. Applied Soil Ecology, vol. 124, pp. 155162. http://dx.doi.org/10.1016/j.apsoil.2017.11.004.

ALVARES, C.A., STAPE, J.L., SENTELHAS, P.C., MORAES, G., LEONARDO, J. and SPAROVEK, G., 2014. Köppen's climate classification map for Brazil. Meteorologische Zeitschrift, vol. 22, no. 6, pp. 711-728. http://dx.doi.org/10.1127/0941-2948/2013/0507.

ARNOLD, A.E. and LUTZONI, F., 2007. Diversity and host range of foliar fungal endophytes: are tropical leaves biodiversity hotspots? Ecology, vol. 88, no. 3, pp. 541-549. http://dx.doi. org/10.1890/05-1459. PMid:17503580.

ARNOLD, A.E., 2007. Understanding the diversity of foliar endophytic fungi: progress, challenges, and frontiers. Fungal Biology Reviews, vol. 21, no. 2-3, pp. 51-66. http://dx.doi.org/10.1016/j. fbr.2007.05.003.

ARNOLD, A.E., MAYNARD, Z. and GILBERT, G.S., 2001. Fungal endophytes in neotropical trees: abundance, diversity, and ecological implications. In K. BAWA, K.N. GANESHAIAH and R. UMA SHAANKER, eds. Tropical ecosystems: structure, diversity and human welfare. New Delhi: Oxford \& IBH Publishing, pp. 739-743.

ARNOLD, A.E., MAYNARD, Z., GILBERT, G.S., COLEY, P.D. and KURSAR, T.A., 2000. Are tropical fungal endophytes hyperdiverse? Ecology Letters, vol. 3, no. 4, pp. 267-274. http://dx.doi.org/10.1046/j.14610248.2000.00159.x.

ARNOLD, A.E., MEJÍA, L.C., KYLLO, D., ROJAS, E.I., MAYNARD, Z., ROBBINS, N. and HERRE, E.A., 2003. Fungal endophytes limit pathogen damage in a tropical tree. Proceedings of the National Academy of Sciences of the United States of America, vol. 100, no. 26, pp. 15649-15654. http://dx.doi.org/10.1073/ pnas.2533483100. PMid:14671327.

ARORA, P., WANI, Z.A., AHMAD, T., SULTAN, P., GUPTA, S. and RIYAZ-UL-HASSAN, S., 2019. Community structure, spatial distribution, diversity and functional characterization of culturable endophytic fungi associated with Glycyrrhiza glabra L. Fungal Biology, vol. 123, no. 5, pp. 373-383. http://dx.doi. org/10.1016/j.funbio.2019.02.003. PMid:31053326.

BASKARATHEVAN, J., JASPERS, M.V., JONES, E.E., CRUICKSHANK, R.H. and RIDGWAY, H.J., 2012. Genetic and pathogenic diversity of Neofusicoccum parvumin New Zealand vineyards. Fungal Biology, vol. 116, no. 2, pp. 276-288. http://dx.doi.org/10.1016/j. funbio.2011.11.010. PMid:22289773.

BASSIMBA, D.D.M., MIRA, J.L., SEDANO, M.E. and VICENT, A., 2017. Control and yield loss modelling of circular leaf spot of persimmon caused by Mycosphaerella nawae. Annals of Applied Biology, vol. 170, no. 3, pp. 391-404. http://dx.doi.org/10.1111/ aab.12343.

BERBEGAL, M., ARMENGOL, J. and GARCÍA-JIMÉNEZ, J., 2011. Evaluation of fungicides to control circular leaf spot of persimmon caused by Mycosphaerella nawae. Crop Protection, vol. 30, no. 11, pp. 1461-1468. http://dx.doi.org/10.1016/j. cropro.2011.05.017.

BEWLEY, J.D., BRADFORD, K., HILHORST, H. and NONOGAKI, H., 2013. Seeds: physiology of development, germination and dormancy. 3rd ed. New York: Springer Science and Business Media, 392 p. http://dx.doi.org/10.1007/978-1-4614-4693-4.

CORDAZZO, C.V., 2002. Effect of seed mass on germination and growth in three dominant species in southern Brazilian coastal dunes. Brazilian Journal of Biology = Revista Brasileira de Biologia, vol. 62, no. 3, pp. 427-435. http://dx.doi.org/10.1590/S151969842002000300005. PMid:12530178.

COUTINHO, R.D., CUEVAS-REYES, P., FERNANDES, G.W. and FAGUNDES, M., 2019. Community structure of gall-inducing insects associated with a tropical shrub: regional, local and individual patterns. Tropical Ecology, vol. 60, no. 1, pp. 74-82. http://dx.doi.org/10.1007/s42965-019-00010-7.

CRAWLEY, M.J., 2013. The R book. 5th ed. Chichester: John Wiley \& Sons, $744 \mathrm{p}$.

DELGADO-SÁNCHEZ, P., ORTEGA-AMARO, M.A., JIMÉNEZ-BREMONT, J.F. and FLORES, J., 2011. Are fungi important for breaking seed dormancy in desert species? Experimental evidence in Opuntia streptacantha (Cactaceae). Plant Biology, vol. 13, no. 1, pp. 154-159. http://dx.doi.org/10.1111/j.1438-8677.2010.00333.x. PMid:21143736.

DELGADO-SÁNCHEZ, P., JIMÉNEZ-BREMONT, J.F., GUERREROGONZÁLEZ, M.L. and FLORES, J., 2013. Effect of fungi and light on seed germination of three Opuntia species from semiarid lands of central Mexico. Journal of Plant Research, vol. 126, no. 5, pp. 643-649. http://dx.doi.org/10.1007/s10265-013-0558-2. PMid:23526153.

DHINGRA, O.D., MAIA, C.B., LUSTOSA, D.C. and MESQUITA, J.B., 2002. Seed borne pathogenic fungi that affect seedling quality of red angico (Anadenanthera macrocarpa) trees in Brazil. Journal of Phytopathology, vol. 150, no. 8-9, pp. 451-455. http://dx.doi. org/10.1046/j.1439-0434.2002.00777.x.

EATON, C.J., COX, M.P. and SCOTT, B., 2011. What triggers grass endophytes to switch from mutualism to pathogenism? Plant Science, vol. 180, no. 2, pp. 190-195. http://dx.doi.org/10.1016/j. plantsci.2010.10.002. PMid:21421360.

FA, A.N., 2019. Endophytic fungi for sustainable agriculture. Microbial Biosystems, vol. 4, no. 1, pp. 31-44. http://dx.doi.org/10.21608/ mb.2019.38886.

FAETH, S.H. and FAGAN, W.F., 2002. Fungal endophytes: common host plant symbionts but uncommon mutualists. Integrative and Comparative Biology, vol. 42, no. 2, pp. 360-368. http:// dx.doi.org/10.1093/icb/42.2.360. PMid:21708729.

FAGUNDES, M., BARBOSA, E.M., OLIVEIRA, J.B., BRITO, B.G., FREITAS, K.T., FREITAS, K.F. and REIS-JUNIOR, R., 2019. Galling inducing insects associated with a tropical shrub: the role of resource concentration and species interactions. Ecología Austral, vol. 29, no. 1, pp. 12-19. http://dx.doi.org/10.25260/EA.19.29.1.0.751.

FAGUNDES, M., CAMARGOS, M.G. and COSTA, F.V., 2011. A qualidade do solo afeta a germinação das sementes e o desenvolvimento das plântulas de Dimorphandra mollis Benth. (Leguminosae: mimosoideae). Acta Botanica Brasílica, vol. 25, no. 4, pp. 908915. http://dx.doi.org/10.1590/S0102-33062011000400018.

FAGUNDES, M., COSTA, F.V., ANTUNES, S.F., MAIA, M.L.B., QUEIROZ, A.C.M.D., OLIVEIRA, L.Q. and FARIA, M.L.D., 2013. The role of historical and ecological factors on initial survival of Copaifera langsdorffii Desf. (Fabaceae). Acta Botanica Brasílica, vol. 27, no. 4, pp. 680-687. http://dx.doi.org/10.1590/S010233062013000400005.

FAGUNDES, M., CUEVAS-REYES, P., ARAUJO, W.S., FARIA, M.L., VALÉRIO, H.M. and SANTOS, H.T., 2020. Influence of light availability and seed mass on germinability and initial growth of two congeneric species of Fabaceae. Acta Botánica Mexicana, vol. 127, e1638. https://dx.doi.org/10.21829/abm127.2020.1638.

FARIAS, J., SANCHEZ, M., ABREU, M.F. and PEDRONI, F., 2015. Seed dispersal and predation of Buchenavia tomentosa Eichler (Combretaceae) in a Cerrado sensu stricto, midwest Brazil. Brazilian Journal of Biology = Revista Brasileira de Biologia, vol. 75, no. 4, suppl. 1, pp. S88-S96. http://dx.doi.org/10.1590/15196984.06214. PMid:26602355.

FENNER, M.K. and THOMPSON, K., 2005. The ecology of seeds. Cambridge: Cambridge University Press, 250 p. http://dx.doi. org/10.1017/CBO9780511614101. 
FERNANDES, E.G., PEREIRA, O.L., SILVA, C.C., BENTO, C.B.P. and QUEIROZ, M.V., 2015. Diversity of endophytic fungi in Glycine max. Microbiological Research, vol. 181, pp. 84-92. http://dx.doi. org/10.1016/j.micres.2015.05.010. PMid:26111593.

FERNANDES, E.G., VALÉRIO, H.M., DUARTE, K.L.R., CAPUCHINHO, L.M.D.N. and FAGUNDES, M., 2019. Fungi associated with Copaifera oblongifolia (Fabaceae) seeds: occurrence and possible effects on seed germination. Acta Botanica Brasílica, vol. 33, no. 1, pp. 179-182. http://dx.doi.org/10.1590/0102-33062018abb0100.

FERREIRA, M.C., CANTRELL, C.L., WEDGE, D.E., GONÇALVES, V.N., JACOB, M.R., KHAN, S., ROSA, C.A. and ROSA, L.H., 2017. Diversity of the endophytic fungi associated with the ancient and narrowly endemic neotropical plant Velloziagigantea from the endangered Brazilian rupestrian grasslands. Biochemical Systematics and Ecology, vol. 71, pp. 163-169. http://dx.doi. org/10.1016/j.bse.2017.02.006.

FISHER, P.J., PETRINI, O., PETRINI, L.E. and SUTTON, B.C., 1994. Fungal endophytes from the leaves and twigs of Quercus ilex L. from England, Majorca and Switzerland. The New Phytologist, vol. 127, no. 1, pp. 133-137. http://dx.doi.org/10.1111/j.1469-8137.1994. tb04267.x. PMid:33874406.

GALLERY, R.E., DALLING, J.W. and ARNOLD, A.E., 2007. Diversity, host affinity, and distribution of seed-infecting fungi: a case study with Cecropia. Ecology, vol. 88, no. 3, pp. 582-588. http:// dx.doi.org/10.1890/05-1207. PMid:17503585.

GAMBOA, M.A. and BAYMAN, P., 2001. Communities of endophytic fungi in leaves of a tropical timber tree (Guareaguidonia: meliaceae). Biotropica, vol. 33, no. 2, pp. 352-360. http://dx.doi. org/10.1111/j.1744-7429.2001.tb00187.x.

GARCIA, A., RHODEN, S.A., BERNARDI-WENZEL, J., ORLANDELLI, R.C., AZEVEDO, J.L. and PAMPHILE, J.A., 2012. Antimicrobial activity of crude extracts of endophytic fungi isolated from medicinal plant Sapindus saponaria L. Journal of Applied Pharmaceutical Science, vol. 2, no. 10, pp. 35-40. http://dx.doi.org/10.7324/ JAPS.2012.21007.

GEISEN, S., KOSTENKO, O., CNOSSEN, M.C., TEN HOOVEN, F.C., VREŠ, B. and VAN DER PUTTEN, W.H., 2017. Seed and root endophytic fungi in a range expanding and a related plant species. Frontiers in Microbiology, vol. 8, no. 1645, pp. 1645. http://dx.doi.org/10.3389/fmicb.2017.01645. PMid:28900420.

GONZAGA, L.L., COSTA, L.E.O., SANTOS, T.T., ARAÚJO, E.F. and QUEIROZ, M.V., 2015. Endophytic fungi from the genus Colletotrichum are abundant in the Phaseolus vulgaris and have high genetic diversity. Journal of Applied Microbiology, vol. 118, no. 2, pp. 485-496. http://dx.doi.org/10.1111/jam.12696. PMid:25410007.

GUARNACCIA, V., VITALE, A., CIRVILLERI, G., AIELLO, D., SUSCA, A., EPIFANI, F., PERRONE, G. and POLIZZI, G., 2016. Characterisation and pathogenicity of fungal species associated with branch cankers and stem-end rot of avocado in Italy. European Journal of Plant Pathology, vol. 146, no. 4, pp. 963-976. http://dx.doi. org/10.1007/s10658-016-0973-z.

HALLOIN, J.M., 1986. Microorganisms and seed deterioration. In: M.B. MCDONALD JUNIOR and C.J. NELSON, eds. Physiology of seed deterioration. Madison: Crop Science Society of America, vol. 11, pp. 89-99.

HARDOIM, P.R., VAN OVERBEEK, L.S., BERG, G., PIRTTILÄ, A.M., COMPANT, S., CAMPISANO, A., DÖRING, M. and SESSITSCH, A., 2015. The hidden world within plants: ecological and evolutionary considerations for defining functioning of microbial endophytes. Microbiology and Molecular Biology Reviews, vol. 79, no. 3, pp. 293-320. http://dx.doi.org/10.1128/MMBR.0005014. PMid:26136581.
HASSAN, O., CHANG, T. and HOSSAIN, A., 2020. Changes in the secondary compounds of persimmon leaves as a defense against circular leaf spot caused by Plurivorosphaerella nawae. PLoS One, vol. 15, no. 3, 0230286. http://dx.doi.org/10.1371/ journal.pone.0230286. PMid:32142558.

HAWKSWORTH, D.L., 2004. Fungal diversity and its implications for genetic resource collections. Studies in Mycology, vol. 50, pp. 9-18.

HE, Y., WANG, M., WEN, S., ZHANG, Y., MA, T. and DU, G., 2007. Seed size effect on seedling growth under different light conditions in the clonal herb Ligularia virgaurea in Qinghai-Tibet plateau. Acta Ecologica Sinica, vol. 27, no. 8, pp. 3091-3108. http://dx.doi. org/10.1016/S1872-2032(07)60063-8.

HIGGINS, K.L., ARNOLD, A.E., COLEY, P.D. and KURSAR, T.A., 2014. Communities of fungal endophytes in tropical forest grasses: highly diverse host-and habitat generalists characterized by strong spatial structure. Fungal Ecology, vol. 8, pp. 1-11. http:// dx.doi.org/10.1016/j.funeco.2013.12.005

ISMAIL, A.M., CIRVILLERI, G., LOMBARD, L., CROUS, P.W., GROENEWALD, J.Z. and POLIZZI, G., 2013. Characterisation of Neofusicoccum species causing mango dieback in Italy. Journal of Plant Pathology, vol. 95, no. 3, pp. 549-557. http://dx.doi. org/10.4454/JPP.V95I3.008.

JIANG, S.J., QIANG, S., ZHU, Y.Z. and DONG, Y.F., 2008. Isolation and phytotoxicity of a metabolite from Curvularia eragrostidis and characterization of its modes of action. Annals of Applied Biology, vol. 152, no. 1, pp. 103-111. http://dx.doi.org/10.1111/j.17447348.2007.00202.x.

KHAN, A.L., GILANI, S.A., WAQAS, M., AL-HOSNI, K., AL-KHIZIRI, S., KIM, Y.H., ALI, L., KANG, S.M., ASAF, S., SHAHZAD, R., HUSSAIN, J., LEE, I.J. and AL-HARRASI, A., 2017. Endophytes from medicinal plants and their potential for producing indole acetic acid, improving seed germination and mitigating oxidative stress. Journal of Zhejiang University. Science. B., vol. 18, no. 2, pp. 125137. http://dx.doi.org/10.1631/jzus.B1500271. PMid:28124841.

KHIRALLA, A., SPINA, R., SALIBA, S. and LAURAIN-MATTAR, D., 2018. Diversity of natural products of the genera Curvularia and Bipolaris. Fungal Biology Reviews, vol. 32, no. 2, pp. 101-122. http://dx.doi.org/10.1016/j.fbr.2018.09.002.

KLUGER, C.G., DALLING, J.W., GALLERY, R.E., SANCHEZ, E., WEEKSGALINDO, C. and ARNOLD, A.E., 2008. Host generalists dominate fungal communities associated with seeds of four neotropical pioneer species. Journal of Tropical Ecology, vol. 24, no. 3, pp. 351-354. http://dx.doi.org/10.1017/S0266467408005026.

KUCHENBECKER, J. and FAGUNDES, M., 2018. Diversity of insects associated with two common plants in the Brazilian Cerrado: responses of two guilds of herbivores to bottom-up and topdown forces. European Journal of Entomology, vol. 115, pp. 354-363. http://dx.doi.org/10.14411/eje.2018.035.

LATA, R., CHOWDHURY, S., GOND, S.K. and WHIT JUNIOR, J.F., 2018. Induction of abiotic stress tolerance in plants by endophytic microbes. Letters in Applied Microbiology, vol. 66, no. 4, pp. 268-276. http://dx.doi.org/10.1111/lam.12855. PMid:29359344.

LAU, M.K., ARNOLD, A.E. and JOHNSON, N.C., 2013. Factors influencing communities of foliar fungal endophytes in riparian woody plants. Fungal Ecology, vol. 6, no. 5, pp. 365-378. http:// dx.doi.org/10.1016/j.funeco.2013.06.003.

LOMBARD, L., VAN LEEUWEN, G.C., GUARNACCIA, V., POLIZZI, G., VAN RIJSWICK, P.C., ROSENDAHL, K.C., GLABER, J. and CROUS, P.W., 2014. Diaporthe species associated with Vaccinium, with specific reference to Europe. Phytopathologia Mediterranea, vol. 53, no. 2, pp. 287-299. 
LUGTENBERG, B.J., CARADUS, J.R. and JOHNSON, L.J., 2016. Fungal endophytes for sustainable crop production. Federation of European Microbiological Societies Microbiology Ecology, vol. 92, no. 12, pp. fiw194. http://dx.doi.org/10.1093/femsec/fiw194. PMid:27624083.

MARTINS, F., PEREIRA, J.A., BOTA, P., BENTO, A. and BAPTISTA, P., 2016. Fungal endophyte communities in above-and belowground olive tree organs and the effect of season and geographic location on their structures. Fungal Ecology, vol. 20, pp. 193-201. http:// dx.doi.org/10.1016/j.funeco.2016.01.005.

MAZAROTTO, E.J., PIMENTEL, I.C., ABREU, D.C.A.D. and SANTOS, A.F.D., 2019. Association of Fusarium and Phomopsis with peroba rosa seeds. Floresta e Ambiente, vol. 26, no. 2, pp. e20170515. http://dx.doi.org/10.1590/2179-8087.051517.

MEEPAGALA, K.M., JOHNSON, R.D. and DUKE, S.O., 2016. Curvularin and dehydrocurvularin as phytotoxic constituents from Curvularia intermedia Infecting Pandanus amaryllifolius. Journal of Agricultural Chemistry and Environment, vol. 5, no. 1, pp. 1222. http://dx.doi.org/10.4236/jacen.2016.51002.

MOLES, A.T. and WESTOBY, M., 2006. Seed size and plant strategy across the whole life cycle. Oikos, vol. 113, no. 1, pp. 91-105. http://dx.doi.org/10.1111/j.0030-1299.2006.14194.x.

MURALI, T.S., SURYANARAYANAN, T.S. and GEETA, R., 2006. Endophytic Phomopsis species: host range and implications for diversity estimates. Canadian Journal of Microbiology, vol. 52, no. 7, pp. 673-680. http://dx.doi.org/10.1139/w06-020. PMid:16917524.

NELSON, E.B., 2004. Microbial dynamics and interactions in the spermosphere. Annual Review of Phytopathology, vol. 42, no. 1, pp. 271-309. http://dx.doi.org/10.1146/annurev. phyto.42.121603.131041. PMid:15283668.

NETTO, M.S., LIMA, W.G., CORREIA, K.C., DA SILVA, C.F., THON, M., MARTINS, R.B., MILLER, R.N.G., MICHEREFF, S.J. and CÂMARA, M.P., 2017. Analysis of phylogeny, distribution, and pathogenicity of Botryosphaeriaceae species associated with gummosis of Anacardium in Brazil, with a new species of Lasiodiplodia. Fungal Biology, vol. 121, no. 4, pp. 437-451. http://dx.doi.org/10.1016/j. funbio.2016.07.006. PMid:28317544.

OLIVEIRA, J.C., SALES, J.F., RUBIO-NETO, A., SILVA, C.F., SOARES, M.A. and SILVA, F.G., 2021. Biological control in the germination of seeds from two species native of the Cerrado region. Brazilian Journal of Biology = Revista Brasileira de Biologia, vol. 81, no. 1, pp. 105-113. http://dx.doi.org/10.1590/1519-6984.222279.

OZASLAN, C., FAROOQ S., ONEN, H., OZCAN, S., BUKUN, B. and GUNAL, H., 2017. Germination biology of two invasive Physalis species and implications for their management in arid and semi-arid regions. Scientific Reports, vol. 7, no. 1, 16960. http:// dx.doi.org/10.1038/s41598-017-17169-5. PMid:29208989.

PAK, D., YOU, M.P., LANOISELET, V. and BARBETTI, M.J., 2017. Reservoir of cultivated rice pathogens in wild rice in Australia. European Journal of Plant Pathology, vol. 147, no. 2, pp. 295-311. http:// dx.doi.org/10.1007/s10658-016-1002-y.

PAVLIC-ZUPANC, D., MALEME, H.M., PIŠKUR, B., WINGFIELD, B.D., WINGFIELD, M.J. and SLIPPERS, B., 2017. Diversity, phylogeny and pathogenicity of Botryosphaeriaceae on non-native Eucalyptus grown in an urban environment: a case study. Urban Forestry $\mathcal{E}$ Urban Greening, vol. 26, pp. 139-148. http://dx.doi.org/10.1016/j. ufug.2017.04.009.

PORRAS-ALFARO, A. and BAYMAN, P., 2011. Hidden fungi, emergent properties: endophytes and microbiomes. Annual Review of Phytopathology, vol. 49, no. 1, pp. 291-315. http://dx.doi. org/10.1146/annurev-phyto-080508-081831. PMid:19400639.
QIN, Y., PAN, X. and YUAN, Z., 2016. Seed endophytic microbiota in a coastal plant and phytobeneficial properties of the fungus Cladosporium cladosporioides. Fungal Ecology, vol. 24, pp. 53-60. http://dx.doi.org/10.1016/j.funeco.2016.08.011.

R CORE TEAM, 2020 [viewed 10 August 2020]. R: a language and environment for statistical computing, version 3.6.3 [online]. Vienna: R Foundation for Statistical Computing. Available from: https://www.R-project.org/

RAI, M., RATHOD, D., AGARKAR, G., DAR, M., BRESTIC, M., PASTORE, G.M. and JUNIOR, M.R.M., 2014. Fungal growth promotor endophytes: a pragmatic approach towards sustainable food and agriculture. Symbiosis, vol. 62, no. 2, pp. 63-79. http:// dx.doi.org/10.1007/s13199-014-0273-3.

REDMAN, R.S., KIM, Y.O., WOODWARD, C.J.D.A., GREER, C., ESPINO, L., DOTY, S.L. and RODRIGUEZ, R.J., 2011. Increased fitness of rice plants to abiotic stress via habitatadapted symbiosis: a strategy for mitigating impacts of climate change. PLoS One, vol. 6, no. 7, e14823. http://dx.doi.org/10.1371/journal.pone.0014823. PMid:21750695.

RIPA, F.A., CAO, W.D., TONG, S. and SUN, J.G., 2019. Assessment of plant growth promoting and abiotic stress tolerance properties of wheat endophytic fungi. BioMed Research International, vol. 2019, 6105865. http://dx.doi.org/10.1155/2019/6105865. PMid:31032353.

RODRIGUEZ, R.J., WHITE JUNIOR, J.F., ARNOLD, A.E. and REDMAN, R.S., 2009. Fungal endophytes: diversity and functional roles. The New Phytologist, vol. 182, no. 2, pp. 314-330. http://dx.doi. org/10.1111/j.1469-8137.2009.02773.x. PMid:19236579.

RUSIN, C., DI FRANCESCO, A., DI FOGGIA, M., D’AQUINO, S., ROMBOLÀ, A., TUGNOLI, V., BOTELHO, R.V. and BARALDI, E., 2019. An emerging problem affecting apple production: neofusicoccum parvum. Aureobasidium pullulans L1 and L8 strains as an alternative control strategy. Biological Control, vol. 134, pp. 157-162. http://dx.doi.org/10.1016/j.biocontrol.2019.04.015.

SAIKKONEN, K., WALI, P., HELANDER, M. and FAETH, S.H., 2004. Evolution of endophyte-plant symbioses. Trends in Plant Science, vol. 9, no. 6, pp. 275-280. http://dx.doi.org/10.1016/j. tplants.2004.04.005. PMid:15165558.

SAKALIDIS, M.L., SLIPPERS, B., WINGFIELD, B.D., HARDY, G.S.J. and BURGESS, T.I., 2013. The challenge of understanding the origin, pathways and extent of fungal invasions: global populations of the Neofusicoccum parvum - N. ribis species complex. Diversity E' Distributions, vol. 19, no. 8, pp. 873-883. http://dx.doi. org/10.1111/ddi.12030.

SILVEIRA, G.F., MELO, M.P., TEIXEIRA, J.W.M., VIANA, D.C., SILVA, J.D.C. and BESERRA JÚNIOR, J.E.A., 2018. First report of Lasiodiplodia theobromae and Pseudofusicoccum stromaticum causing dieback in Syzygium malaccense tree in Brazil. Forest Pathology, vol. 48, no. 2, pp. e12408. http://dx.doi.org/10.1111/efp.12408.

SOUZA, M.L. and FAGUNDES, M., 2014. Seed size as key factor in germination and seedling development of Copaifera langsdorffii (Fabaceae). American Journal of Plant Sciences, vol. 5, no. 17, pp. 2566-2573. http://dx.doi.org/10.4236/ajps.2014.517270.

TILLEY, A.M. and WALKER, H.L., 2002. Evaluation of Curvularia intermedia (Cochliobolusintermedius) as a potential microbial herbicide for large crabgrass (Digitariasanguinalis). Biological Control, vol. 25, no. 1, pp. 12-21. http://dx.doi.org/10.1016/ S1049-9644(02)00035-X.

TUDZYNSKI, B. and SHARON, A., 2002. Biosynthesis, biological role and application of fungal phytohormones. In: H.D. OSIEWACZ, ed. Industrial applications. Berlin: Springer, pp. 183-211. http:// dx.doi.org/10.1007/978-3-662-10378-4_9. 
U'REN, J.M., DALLING, J.W., GALLERY, R.E., MADDISON, D.R., DAVIS, E.C., GIBSON, C.M. and ARNOLD, A.E., 2009. Diversity and evolutionary origins of fungi associated with seeds of a neotropical pioneer tree: a case study for analysing fungal environmental samples. Mycological Research, vol. 113, no. 4, pp. 432-449. http://dx.doi.org/10.1016/j.mycres.2008.11.015. PMid:19103288.

U'REN, J.M., LUTZONI, F., MIADLIKOWSKA, J., LAETSCH, A.D. and ARNOLD, A.E., 2012. Host and geographic structure of endophytic and endolichenic fungi at a continental scale. American Journal of Botany, vol. 99, no. 5, pp. 898-914. http://dx.doi.org/10.3732/ ajb.1100459. PMid:22539507.

VELOSO, A.C., SILVA, P.S., SIQUEIRA, W.K., DUARTE, K.L., GOMES, I.L., SANTOS, H.T. and FAGUNDES, M., 2017. Intraspecific variation in seed size and light intensity affect seed germination and initial seedling growth of a tropical shrub. Acta Botanica Brasílica, vol. 31, no. 4, pp. 736-741. http://dx.doi.org/10.1590/0102$33062017 a b b 0032$.

WAGNER, B.L. and LEWIS, L.C., 2000. Colonization of corn, Zea mays, by the entomopathogenic fungus Beauveriabassiana. Applied and
Environmental Microbiology, vol. 66, no. 8, pp. 3468-3473. http:// dx.doi.org/10.1128/AEM.66.8.3468-3473.2000. PMid:10919808.

WALKER, H.L. and TILLEY, A.M., 1997. Control of crabgrass with a fungal pathogen. United States Patent No. 5,635,444.

WALKER, H.L. and TILLEY, A.M., 1999. Control of crabgrass with a fungal pathogen. United States Patent No. 5,952,264.

WHITE, T.J., BRUNS, T., LEE, S.J.W.T. and TAYLOR, J.L., 1990. Amplification and direct sequencing of fungal ribosomal RNA genes for phylogenetics. PCR Protocols: a Guide to Methods and Applications, vol. 18, no. 1, pp. 315-322. http://dx.doi.org/10.1016/ B978-0-12-372180-8.50042-1.

ZAKARIA, L. and AZIZ, W.N.W., 2018. Molecular identification of endophytic fungi from banana leaves (Musa spp.). Tropical Life Sciences Research, vol. 29, no. 2, pp. 201-211. http://dx.doi. org/10.21315/tlsr2018.29.2.14. PMid:30112150.

ZHU, Y. and QIANG, S., 2004. Isolation, pathogenicity and safety of Curvulariaeragrostidis isolate QZ-2000 as a bioherbicide agent for large crabgrass (Digitariasanguinalis). Biocontrol Science and Technology, vol. 14, no. 8, pp. 769-782. http://dx.doi.org/10.10 $80 / 09583150410001720699$ 